Sejak awal berdiri, Sarekat Islam sudah lahir dengan nafas dakwah. Para pendiri sudah memiliki keinginan untuk menanamkan ketauhidan dan memperbaiki moralitas kaum pribumi. Jalan dakwah kemudian semakin terbuka lebar ketika Sarekat Islam terlembagakan dalam suatu organisasi yang diakui pemerintah Hindia Belanda dan dikelola dengan modern. Tokoh-tokoh seperti H. Samanhudi, H.O.S Tjokroamnito dan tokoh lain kemudian mengambil peranan penting sehingga pengikut Sarekat Islam berkembang pesat, tidak hanya di pulau Jawa tapi juga berkembang hingga ke tanah Sumatera, Kalimantan hingga Sulawesi.

Meskipun pada akhirnya dakwah Sarekat Islam harus terhenti karena tuntutan dinamika politik yang terjadi di nusantara, tetapi kejayaan dakwahnya pada dasawarsa kedua abad ke-20 itu sangat patut untuk diapresiasi dan dijadikan pembelajaran. Apalagi dalam konteks dakwah kontemporer, pembelajaran dari sepak terjang yang dilalui oleh organisasi pimpinan Tjokroaminoto ini tentu begitu berharga, bukan hanya karena Sarekat Islam adalah organisasi Islam terbesar pada masanya, melainkan juga sebagai bentuk penghargaan terhadap sejarah bangsa. Selain itu, yang perlu menjadi catatan penting lainnya, semua sepak terjang dakwah Sarekat Islam tentu tidak dapat dilepaskan dari konteks pergerakan nasional. Ciri khas dari pergerakan masa itu adalah berkembangnya ide kebangsaan, semangat politik dan nasionalisme menjadi simpul perjuangan semua organisasi yang hidup kala itu, tak terkecuali bagi Sarekat Islam sendiri.

Buku ini diharapkan dapat memberikan wacana baru, baik untuk perkembangan ilmu dakwah maupun sejarah perkembangan Islam di Indonesia. Buku ini dapat dibaca oleh siapa saja, terlebih bagi mereka yang memiliki perhatian terhadap dunia dakwah dan perkembangan Islam.
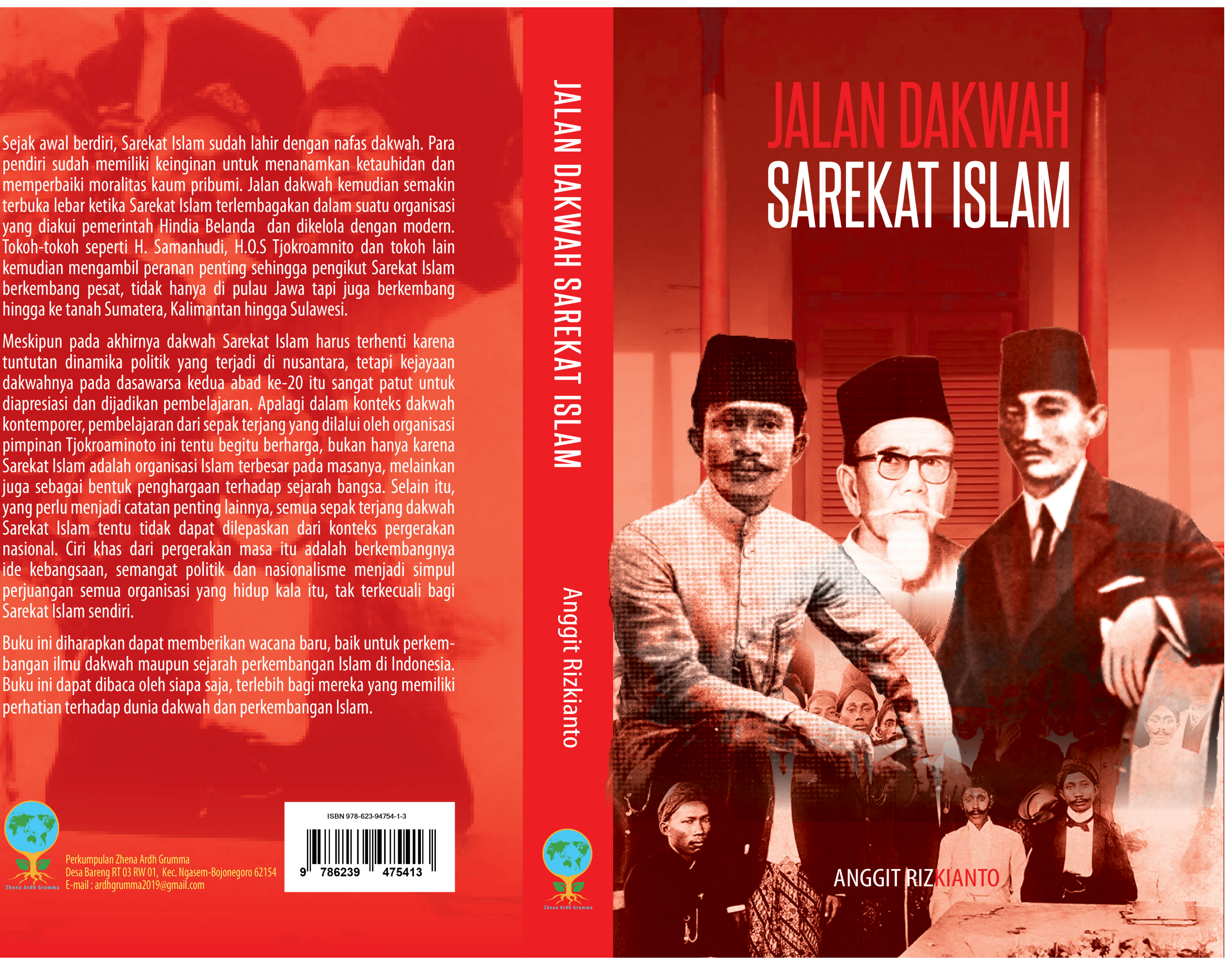


\section{JALAN DAKWAH \\ SAREKAT ISLAM}




\section{Sanksi Pelanggaran Pasal 113 \\ Undang Undang Nomor 28 Tahun 2014 Tentang Hak Cipta}

(1) Setiap Orang yang dengan tanpa hak melakukan pelanggaran hak ekonomi sebagaimana dimaksud dalam Pasal 9 ayat (1) huruf i untuk Penggunaan Secara Komersial dipidana dengan pidana penjara paling lama 1 (satu) tahun dan/atau pidana denda paling banyak Rp100.000.000 (seratus juta rupiah).

(2) Setiap Orang yang dengan tanpa hak dan/atau tanpa izin Pencipta atau pemegang Hak Cipta melakukan pelanggaran hak ekonomi Pencipta sebagaimana dimaksud dalam Pasal 9 ayat (1) huruf c, huruf d, huruf f, dan/atau huruf h untuk Penggunaan Secara Komersial dipidana dengan pidana penjara paling lama 3 (tiga) tahun dan/atau pidana denda paling banyak Rp500.000.000,00 (lima ratus juta rupiah).

(3) Setiap Orang yang dengan tanpa hak dan/atau tanpa izin Pencipta atau pemegang Hak Cipta melakukan pelanggaran hak ekonomi Pencipta sebagaimana dimaksud dalam Pasal 9 ayat (1) huruf a, huruf b, huruf e, dan/atau huruf g untuk Penggunaan Secara Komersial dipidana dengan pidana penjara paling lama 4 (empat) tahun dan/ atau pidana denda paling banyak Rp1.000.000.000,00 (satu miliar rupiah).

(4) Setiap Orang yang memenuhi unsur sebagaimana dimaksud pada ayat (3) yang dilakukan dalam bentuk pembajakan, dipidana dengan pidana penjara paling lama 10 (sepuluh) tahun dan/atau pidana denda paling banyak Rp4.000.000.000,00 (empat miliar rupiah). 


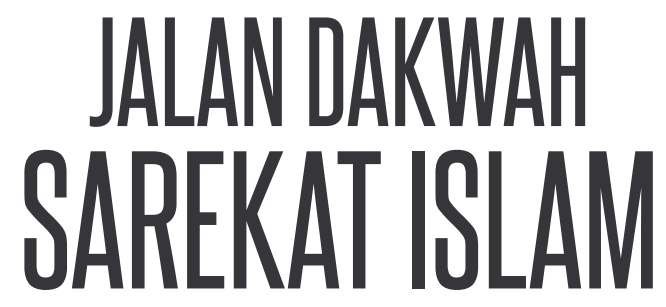

Anggit Rizkianto

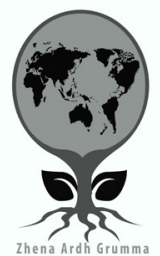




\title{
JALAN DAKWAH SAREKAT ISLAM
}

\author{
Penulis \\ Anggit Rizkianto \\ Diterbitkan oleh \\ Perkumpulan Zhena Ardh Grumma \\ Desa Bareng RT 03 RW 01 \\ Kec. Ngasem-Bojonegoro 62154 \\ E-mail : ardhgrumma2019@gmail.com
}

\author{
Cetakan I, Juni 2020 \\ xii +308 hlm.; $13,5 \mathrm{~cm} \times 21 \mathrm{~cm}$ \\ ISBN: 978-623-94754-1-3
}

Hak Cipta Dilindung Undang-Undang

All rights reserved 
Anggit Rizkianto $\sim v$

Untuk almarhum ayahku tercinta, dan teman-teman seperjuangan di Yayasan Al-Kahfi. 
vi Jalan Dakwah Sarekat Islam 


\title{
PENGANTAR
}

\begin{abstract}
CAREKAT Islam sebagai suatu organisasi yang bergerak di jalan dakwah masih belum banyak dikaji, baik dalam ruang lingkup keagamaan maupun kesejarahan Indonesia. Sejauh ini, kajian mengenai Sarekat Islam banyak terfokus pada pergerakan politiknya, perjuangannya sebagai organisasi pergerakan nasional, maupun kemampuannya dalam menyelesaikan konflikkonflik di internal organisasi. Maka, mengkaji Sarekat Islam melalui "kaca mata" pergerakan dakwah Islam akan menjadi kajian yang menarik dan tergolong baru. Itulah dasar pemikiran dari penulisan buku ini.

Ada banyak kajian mengenai Sarekat Islam, baikyang berasal dari sarjana dalam negeri maupun luar negeri, yang menjadi rujukan buku ini. Misalnya saja yang paling komprehensif adalah kajian dari A.P.E Korver yang berjudul "Sarekat Islam: Gerakan Ratu Adil", atau karya dari Safrizal Rambe dengan judul "Sarekat Islam: Pelopor Bangkitnya Nasionalisme Indonesia 1905-1942" dan dari Anton Timur Djaelani dengan judul "Gerakan Sarekat Islam: Kontribusinya pada Nasionalisme Indonesia". Hormat
\end{abstract}


setinggi-tingginya kepada mereka serta penulis lainnya yang karyanya dirujuk dalam buku ini. Dengan berbagai rujukan kepustakaan tersebut, maka gerakan Sarekat Islam dapat dibaca dengan berbagai macam alat analisis untuk menggambarkan gerakan dakwahnya, misalnya dengan perangkat ilmu dakwah sendiri, manajemen, organisasi, kepemimpinan, komunikasi, bahkan ilmu-ilmu pemasaran modern.

Sejak awal berdiri, Sarekat Islam sudah lahir dengan nafas dakwah. Para pendiri sudah memiliki keinginan untuk menanamkan ketauhidan dan memperbaiki moralitas kaum pribumi. Jalan dakwah kemudian semakin terbuka lebar ketika Sarekat Islam terlembagakan dalam suatu organisasi yang diakui pemerintah Hindia Belanda dan dikelola dengan modern.Tokohtokoh seperti H. Samanhudi, H.O.S Tjokroamnito dan tokoh lain kemudian mengambil peranan penting sehingga pengikut Sarekat Islam berkembang pesat, tidak hanya di pulau Jawa tapi juga berkembang hingga ke tanah Sumatera, Kalimantan hingga Sulawesi. Di tanah Jawa, dakwah Sarekat Islam sangat terbantu oleh media-media yang dimiliki dan dikelola para kader, mulai dari Saratomo, Kaoem Moeda, Oetoesan Hindia dan Pantjaran Warta. Media-media itu selalu berperan dalam setiap penyebaran pemikiran dan perubahan akhlak pribumi yang menjadi semangat Sarekat Islam. Namun, tak dapat dipungkiri juga bahwa ada banyak dinamika dan tantangan yang dihadapi Sarekat Islam pada setiap dakwahnya itu, baik yang berasal dari internal Sarekat Islam sendiri maupun dari pihak eksternal. Meskipun pada akhirnya dakwah Sarekat Islam harus terhenti karena tuntutan dinamika politik yang terjadi di nusantara, tetapi kejayaan dakwahnya pada dasawarsa kedua abad ke-20 
itu sangat patut untuk diapresiasi dan dijadikan pembelajaran. Apalagi dalam konteks dawah kontemporer, pembelajaran dari sepak terjang yang dilalui oleh organisasi pimpinan Tjokroaminoto ini tentu begitu berharga, bukan hanya karena Sarekat Islam adalah organisasi Islam terbesar pada masanya, melainkan juga sebagai bentuk penghargaan terhadap sejarah bangsa. Selain itu, yang perlu menjadi catatan penting lainnya, semua sepak terjang dakwah Sarekat Islam tentu tidak dapat dilepaskan dari konteks pergerakan nasional. Ciri khas dari pergerakan masa itu adalah berkembangnya ide kebangsaan, semangat politik dan nasionalisme menjadi simpul perjuangan semua organisasi yang hidup kala itu, tak terkecuali bagi Sarekat Islam sendiri.

Dengan berbagai keterbatasan dan kekurangannya, setidaknya buku ini diharapkan dapat memberikan wacara baru, baik untuk perkembangan ilmu dakwah maupun sejarah perkembangan Islam di Indonesia. Buku ini dapat dibaca oleh siapa saja, terlebih bagi mereka yang memiliki perhatian terhadap dunia dakwah dan perkembangan Islam.

Surabaya, 1 Juni 2020

Penulis 
$x \sim$ Jalan Dakwah Sarekat Islam 


\section{DAFTAR ISI}

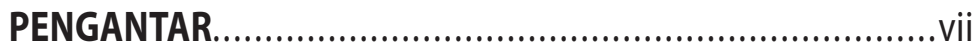

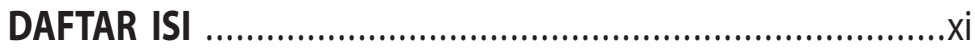

BAB I Latar Belakang Gerakan Dakwah di Indonesia ...............1

Wacana Kebangkitan Islam ........................................

Kebangkitan Islam di Indonesia ..............................18

Kebijakan Politik Etis Hindia Belanda...........................35

Dari Kebangkitan Islam Menuju Wacana

Pembaharuan Islam...................................................42

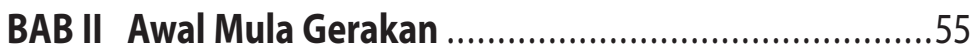

Dari Rekso Rumekso sampai Sarekat Islam ..................57

Akar Pemikiran Sarekat Dagang Islam ......................68

Pemikiran H. Samanhudi ........................................78

Semangat Keumatan H.O.S.Tjokroaminoto...................88

Menuju Kelembagaan Sarekat Islam.........................102

BAB III Antara Dakwah Islamiyah dan Perjuangan

Kemerdekaan.......................................................118

Misi Ketauhidan Sarekat Islam ..............................119 
Membela Kepentingan Pribumi.............................132

Melawan Kolonialisme.......................................... 144

Menuju Kemerdekaan .......................................152

Ambisi Perbaikan Moralitas.................................. 164

BAB IV Tokoh-Tokoh Sentral dan Media Perjuangan ........175

Ketokohan Tjokroaminoto ..................................176

Agus Salim dan Peranannya ...............................190

Abdul Moeis dan Perananannya...........................206

Marco Kartodikromo dan Media-Media Sarekat Islam ......225

BAB V Kemunduran dan Pertahanan Diri....................................249

Memudarnya Gerakan Sarekat Islam.......................250

Periode Pertahanan Diri......................................270

Pelajaran dari Gerakan Sarekat Islam......................280

DAFTAR PUSTAKA..................................................296

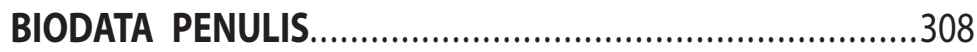




\section{BAB I \\ LATAR BELAKANG GERAKAN DAKWAH DI INDONESIA}

EMPERTANYAKAN asal mula gerakan dakwah di Indonesia bukanlah perkara mudah. Dakwah islamiyah di tanah air sudah berlangsung sejak berabad-abad yang lalu, jauh sebelum Indonesia sebagai suatu bangsa dan negara terbentuk. Para alim ulama dan wali sudah melakukan proses islamisasi sebagai bentuk pengabdian akan hidupnya bahkan sejak sebelum abad ke-10. Akan tetapi, memaknai dakwah sebagai suatu pergerakan tentu diperlukan pandangan yang cukup kritis. Artinya dakwah tidak sekadar dipahami sebagai suatu seruan untuk mengubah pandangan masyarakat, atau mengubah cara pandang akan konsep ketuhanan dan menanamkan ketauhidan. Dalam suatu pergerakan, anasir paling dasarnya adalah progresivitas, suatu upaya untuk bergerak maju. Kemajuan dari suatu peradaban di berbagai sektor menjadi cita-cita bersama kaum muslimin yang menempuh jalan-jalan dakwah, yang dimotori oleh suatu gerakan dengan semangat tinggi. Gerakan tersebut diisi oleh orang-orang yang tentunya memiliki militansi. Maka dari itu, jika melihat gerakan-gerakan dakwah di dunia Islam selalu tampak 
pergerakan tersebut menginginkan perubahan yang bersifat mendasar demi suatu cita-cita masyarakat yang dipandang ideal. Ada rasa ketidakpuasaan dari tatanan sosial masyarakat yang sudah ada. Dengan kata lain, ada suatu kesadaran bahwa dunia Islam telah terpuruk sekian lama dan diperlukan suatu usaha untuk membangkitkannya kembali.

Demi mencapai apa yang menjadi tujuan, pergerakan selalu terorganisasir, memiliki asas yang jelas serta ideologi, sehingga dapat berperan serta dalam menciptakan peradaban yang maju. ${ }^{1}$ Lebih dari itu, suatu gerakan juga dapat dimaknai sebagai aktivitas sosial, yang tumbuh di tengah-tengah masyarakat secara kolektif dan bersifat informal. Umumnya tentu berbentuk organisasi, yang terdiri dari banyak orang yang saling bekerja sama. Mereka memiliki kepedulian terhadap isu-isu sosial dan melakukan aktivitas dalam banyak dimensi, baik sosial, budaya, maupun politik. Inti dari perjuangannya adalah menginginkan perubahan sosial. ${ }^{2}$ Dari perspektif sosiologis, konsep pergerakan selalu ditekankan pada aspek kolektif dan bersifat sosial. Selanjutnya ditekankan pula adanya aspek kesengajaan, sehingga gerakan itu melahirkan organisasi dan gerakannya selalu berkesinambungan. Sebagai akibat dari pemahaman bahwa gerakan adalah suatu aksi kolektif, maka gerakan tersebut diyakini berlangsung dalam jangka waktu yang sangat lama, seiring dengan peradaban manusia yang juga telah berlangsung lama. Artinya perubahan dari satu peradaban ke peradaban yang lain tak dapat dilepaskan

Basrowi \& Sukidin, Teori-Teori Perlawanan dan Kekerasan Kolektif (Surabaya: Insan Cendikia, 2003), 17.

2) AB Widyanta, Problem Modernitas dalam Kerangka (Yogyakarta: Cinelaras Pustaka Rakyat Cerdas, 2002), 12. 
dari adanya pergerakan itu, yang dapat berlangsung secara damai maupun secara berkonflik. ${ }^{3}$

\section{Wacana Kebangkitan Islam}

Dalam suatu seminar yang diikuti oleh mantan rektor UIN Syarif Hidayatullah, pernah dikatakan bahwa kebangkitan Islam lebih berpeluang terjadi di wilayah Asia Tenggara dari pada di Timur Tengah. Alasannya karena Asia Tenggara berada di wilayah yang sangat strategis, berada pada posisi yang menghubungkan dua jalur laut yang ramai oleh jalur pelayaran. Jalur pertama yang menghubungkan timur dan barat, yaitu Samudera Hindia dengan Samudera Pasifik. Jalur kedua yang menghubungkan utara dan selatan, yaitu wilayah Asia Timur dengan Wilayah Australia dan Selandia Baru. Indonesia sendiri memiliki tiga pintu utama untuk memasuki kawasan Asia Tenggara, yaitu Selat Malaka, Selat Sunda dan Selat Lombok. Ketiga selat tersebut diyakini sebagai titik pusat perdagangan dunia selama berabad-abad. Secara politik dan ekonomi, ketiganya memainkan peran penting dalam berbagai konflik yang menyangkut perebutan kawasan Laut Cina Selatan. Selat Malaka juga menjadi selat tersibuk karena satu-satunya jalur terpendek yang menghubungkan kawasan India, Indonesia dan Tiongkok. Lebih dari itu, selat tersebut juga menjadi jalur laut yang vital bagi perekonomian Jepang, Republik Korea, Tiongkok dan Amerika Serikat, khususnya dalam urusan perdagangan. Maka, tidak berlebihan jika kemudian selat yang berada di ujung Sumatera itu dijuluki "chokepoints" Asia. ${ }^{4}$

3) Miftah Thoha, Kepemimpinan dalam Manajemen: Suatu Pendekatan Perilaku (Jakarta: Raja Grafindo Persada, 1995), 63.

4) Abdul Ghofur, "Kebangkitan Islam Indonesia (Tela'ah tentang Munculnya Ormas Islam Awal Abad 20 M)", Toleransi: Media IImiah Komunikasi Umat Beragama, Vol. 4, No. 2, Juli-Desember 2012, 115. 
Kebangkitan Islam (Islamic Resurgence) kerap diartikan sebagai suatu gerakan yang bertujuan menyadarkan kepada masyarakat bahwa Islam adalah hal yang penting, dengan cara mengaitkan pada masa lalu Islam itu sendiri, yang pernah mencapai puncak kejayaan dan kegemilangan sehingga banyak mempengaruhi pemikiran-pemikiran umat Islam di masa sekarang. Dengan kata lain, menyadarkan kepada masyarakat bahwa Islam adalah satu-satunya solusi untuk memperbaiki keadaan umat yang terpuruk. Kejayaan Islam masa lalu kerap kali disandarkan pada selama kurang lebih tujuh abad pertama sejak lahirnya Islam, yang dimulai dari masa Kerasulan (23 tahun), Kekhalifahan Khulafaurrasyidin (30 tahun), Kekhalifahan Umayyah (90 tahun) dan Kekhalifahan Abbasiyah (500 tahun). ${ }^{5}$ Masa-masa itu adalah masa-masa yang paling mempengaruhi perkembangan Islamselanjutnya hingga masa sekarang.Kejayaan masa lalu selalu menjadikan Islam sebagai pemikiran dan solusi alternatif atas berbagai keterpurukan yang dialami oleh umat muslim setelahnya. Keterpurukan umat Islam sendiri dimulai sejak jatuhnya Abbasiyah pada abad ke-13 hingga maraknya kolonialisme yang menimpa bangsa-bangsa Islam hingga abad ke-20. Dalam bingkai dunia Islam, masa-masa kebangkitan itu telah dimulai sejak abad ke-19 dan gelombangnya terus membesar hingga abad ke-20. Tokoh-tokoh kebangkitan Islam itu pada mulanya adalah Jamaluddin al-Afghani, Moh. Abduh, Rasyid Ridha, dan beberapa tokoh lain. Apa yang diperjuangkan oleh tokoh-tokoh tersebut lantas turut memberikan pengaruh yang cukup kuat pada gerakan-gerakan Islam di kawasan Asia

5) Harun Nasution, Islam ditinjau dari Beberapa Aspeknya Jilid I (Jakarta: UI Press, 1985), 57. 
Tenggara, khususnya Indonesia. ${ }^{6}$

Ada beberapa faktor yang mendorong gerakan kebangkitan Islam yang menekankan pada pentingnya kembali ke jalan Islam agar bangkit dari keterpurukan. Faktor pertama adalah maraknya kolonialisme yang dilakukan oleh bangsa-bangsa Eropa mulai dari Portugal, Spanyol, Inggris hingga Belanda. Bangsa-bangsa Barat itu datang ke kawasan-kawasan bangsa muslim untuk mengeksploitasi alam, mengambil alih pemerintahannya dan melakukan kristenisasi. Faktor kedua adalah munculnya masalah dari internal umat Islam sendiri, yaitu paham taklid yang berkembang di kalangan orang-orang Islam di mana mereka tunduk patuh pada pendapat ulama, mengkultuskan para wali dan meninggalkan kajian-kajian Islam yang membahas filsafat dan ilmu pengetahuan.

Berbicara mengenai kolonialisme, secara politis umat Islam telah berada di bawah kendali kolonialisme sejak era sejarah peradaban Islam modern, kurang lebih saat memasuki abad ke-19. Hal tersebut tidak dapat dilepaskan dari kemunduran tiga Kerajaan Islam yang masih tersisa sampai abad ke-18, yang dalam waktu bersamaan bangsa-bangsa Eropa justru mengalami kemajuan pesat. Kerajaan Safawi sudah mengalami kehancuran pada awal abad ke-18. Kerajaan Mughal yang menguasai wilayah India ditaklukkan oleh Inggris pada pertengahan abad ke-19. Umat Islam sempat berharap pada kekuatan Islam yang terakhir, yaitu Turki Utsmani.? Sayangnya, kerajaan itu juga mengalami kemunduran karena berbagai masalah yang sangat kompleks

6) Saiful Muzani, Kebangkitan Islam Di Asia Tenggara (Jakarta: LP3ES, 1999), 34.

7) Badri Yatim, Sejarah Peradaban Islam, Dirasah Islamiyah II (Jakarta: Raja Grafindo Persada, 2016), 174. 
sehingga dijuluki The Sick Man of Europe oleh bangsa-bangsa Eropa. Meskipun ada pendapat yang mengatakan bahwa melemahnya kekuatan Islam di tiga kerajaan tersebut disebabkan adanya disintegrasi politik, di mana munculnya penguasapenguasa baru di berbagai daerah wilayah kerajaan sementara otoritas pemerintah pusat sangat lemah. Akan tetapi, faktor-faktor lain tentu tidak dapat disangkal, seperti hancurnya moralitas dan spiritualitas masyarakat dan penguasa serta kekalahan Islam dalam hal persaingan dagang dengan bangsa-bangsa Eropa. Ada pula yang berpendapat kekalahan perang juga menjadi sebab melemahnya kekuatan kerajaan-kerajaan Islam itu. ${ }^{8}$

Tidak berdayanya lagi kekuatan-kekuatan Islam lantas membuat Bangsa-Bangsa Eropa dapat dengan mudah mengambil alih wilayah-wilayah yang sebelumnya berada dibawah kekuasaan Islam. Dunia Islam baru banyak mengambil tindakan untuk memerdekakan dirinya pada awal abad ke-20 dengan berbagai jalan. Berbagai upaya dan perjuangan itu adalah manifestasi dari kebangkitan Islam itu sendiri. ${ }^{9}$ Kemudian, ada juga yang berpendapat bahwa munculnya nasionalisme kebangsaan yang berorentasi pada kemerdekaan juga manifestasi dari lahirnya kebangkitan Islam. ${ }^{10}$ Selama masa kolonialisme, umat Islam mengalami banyak kemunduran dari berbagai aspek, tidak hanya aspek politik dan ekonomi saja. Agama, moralitas, budaya, pendidikan dan ilmu pengetahuan juga mengalami kemunduran

\footnotetext{
8) Munawir Sjadzali, Islam dan Tata Negara Ajaran, Sejarah dan Pemikiran (Jakarta: UI Press, 1993), 111.

9) Harun Nasution, Islam ditinjau dari berbagai aspeknya (Jakarta: UI Press, 2002), 88.

10) Badri Yatim, Sejarah Peradaban Islam, Dirasa Islamiyah II (Jakarta: Raja Grafindo Persada, 2008), 184.
} 
karena berbagai macam tak tik penjajahan yang dilakukan oleh bangsa Barat. Lambat laun, umat Islam menjadi bangsa yang marjinal dalam pentas politik dunia dan selalu dipandang sebelah mata. Ironisnya, selama berabad-abad umat Islam sendiri tidak menyadari akan permasalahan tersebut karena kebanyakan dari mereka juga dirusak pemikirannya oleh kolonialisme.

Beruntunglah kemudian bibit-bibit perlawanan dapat tumbuh di berbagai negara sehingga secara perlahan menanamkan kesadaran dan membangun akhlak kaum muslimin untuk lepas dari penjajahan dan kemerosotan umat. Bahkan, membangkitkan kembali kejayaan Islam dipandang sebagai suatu kewajiban, untuk membentuk bangsa "Baldatun Toyyibatun wa Rabbun Gafur". Pada saat yang sama, juga muncul pemikiran-pemikiran pembaharuan Islam. Munculnya pemikiran pembaharuan itu disebabkan oleh kesadaran para ulama Islam yang mulai berpikir bahwa ajaran-ajaran asing yang dibawa oleh bangsa Barat dan diterima dunia Islam cenderung membahayakan. Menurut pandangan banyak ulama pada masa-masa itu, ajaran-ajaran asing tersebut bertentangan dengan substansi ajaran Islam yang sesungguhnya. Lebih dari itu, para ulama menganggap justru ajaran itu yang menyebabkan Islam mengalami kemunduran. Dengan semangat membangkitkan kembali kejayaan Islam, para ulama bermaksud untuk membersihkan kembali ajaran Islam. Ada yang menyatakan bahwa yang dilakukan oleh ulama pembaharuan adalah gerakan reformasi Islam. Di sisi lain, pada periode-periode itu bangsa Barat sangat mendominasi politik dan pemerintahan yang membuat para ulama dapat bersentuhan dengan perkembangan dunia barat. Persentuhan itu lantas menyadarkan mereka bahwa Islam telah tertinggal jauh dari 